\title{
The analysis of petroleum hydrocarbons in soils deriving from areas of various development
}

\author{
Ewa Badowska $^{1, *}$, and Dawid Bandzierz ${ }^{1}$ \\ ${ }^{1}$ Lodz University of Technology, Institute of Environmental Engineering and Building Installations, \\ 90-924 Lodz, Al. Politechniki 6, Poland
}

\begin{abstract}
The petroleum pollutants are one of the basic soil contaminants. This is due to the widespread use of petroleum products. Crude oil and its derivatives appear in the environment mainly during their storage and transport. In the research, 16 soil samples from different places were collected and analysed. The selected locations were divided into agricultural, service, recreational, residential and industrial use. The petroleum hydrocarbons were determined, in the range from $\mathrm{C} 10$ to $\mathrm{C} 40$, according to the standard PN-EN ISO 16703 [1] by means of gas chromatography. The determined results were mostly above the limited values [2] resulting from matching the soil to the group to which the specific area belongs.
\end{abstract}

\section{Introduction}

Petroleum substances together with heavy metals are the most common soil environment pollutants [3]. In the case of heavy metals, the occurrence of various metals in environment is analysed, depending on the possibility of their occurrence in the area. Literature data mainly concern the content of $\mathrm{Cu}$ (copper), $\mathrm{Cr}$ (chromium), $\mathrm{Pb}$ (lead), $\mathrm{Zn}$ (zinc), $\mathrm{Cd}$ (cadmium), Ni (nickel), but also Fe (iron), As (arsenic), Mn (manganese), or $\mathrm{Ti}$ (titanium) in soil. They are analysed both in industrial and urban areas [4-6]. In the case of petroleum pollutants, soil is most often analysed regarding the presence of polycyclic aromatic hydrocarbons (PAHs) [7-9] or in general considering the amount of total petroleum hydrocarbon (TPH) (in this case, depending on the used methodology, the range of compounds being tested is different).

Crude oil and its derivatives appear in the environment mainly during its storage and transport. Events such as spills oil are particularly dangerous for the environment because the contaminant fills the soil pores changing its parameters, and then it can reach the groundwater level and pollute it too [10]. In addition, petroleum pollutants limit or completely block the free flow of water and air in the soil. The situation when the content of petroleum hydrocarbons in the soil is high is particularly unfavourable for the soil. Then the bacteria and fungi present in the soil consume all available nitrogen, phosphorus and oxygen [11]. Soil contamination is associated with its impact on the ecosystem, in the case

* Corresponding author: ewa.badowska@p.lodz.pl 
of plants it may be associated with their growth, in the case of animals it affects the development of diseases caused by being in a polluted environment [12].

The analyses of petroleum hydrocarbons content in soil are made mainly in places located in the vicinity of objects that affect or may have a negative impact on the soil environment. Exemplary research concerns soils from industrial areas, petrol stations, but also from farmland located near petrol activity.

The example of the analyses of soil quality in industrial areas are studies carried out in Italy in three different locations. The content of petroleum pollutants determined as THC was up to $179.33 \mathrm{mg} / \mathrm{kg}$, however, most of the samples were below the acceptable value in Italy $(50 \mathrm{mg} / \mathrm{kg})$ [13]. On the other hand, in areas considerably contaminated, the content of $\mathrm{TPH}$ in the soil can be significantly higher and equal more than $80000 \mathrm{mg} / \mathrm{kg}$ [14]. The research on the total petroleum hydrocarbon content was also carried out in the Macabarie Island subantarctic area, selecting sites exposed to oil and gas (fuel farm and powerhouse). For samples from the depth of $0.5 \mathrm{~m}$, the hydrocarbon content was in the range from below the level of determination to about $740 \mathrm{mg} / \mathrm{kg}$ [15]. In other studies, in soil samples from the area of fuel terminal, the hydrocarbon content in the range above $\mathrm{C}_{12}$ was the $32147.85 \mathrm{mg} / \mathrm{kg}$ at $0.3 \mathrm{~m}$ depth, while at a depth of $2.0 \mathrm{~m}$ was $3938.2 \mathrm{mg} / \mathrm{kg}$ [16].

In the studies of soil contamination with petroleum hydrocarbons carried out in the area of petrol stations located in various places, the maximum values of total petroleum hydrocarbon in the range from $79.9 \mathrm{mg} / \mathrm{kg}$ to $956.9 \mathrm{mg} / \mathrm{kg}$ were determined. For individual locations, the maximum values were determined from various depths [17]. In another case, soil samples originating from the areas of two fuel stations, contained $9367 \mathrm{mg} / \mathrm{kg}$ and $8075 \mathrm{mg} / \mathrm{kg}$ of petroleum hydrocarbons respectively [18].

The research of soil samples from farmland located no more than $100 \mathrm{~m}$ from oil wells showed that the pollution with petroleum compounds (as a sum of n-alkanes) was below $40 \mathrm{mg} / \mathrm{kg}$, much higher values were determined for wasteland located within a radius of $20 \mathrm{~m}$ from the source of pollution (even $460.79 \mathrm{mg} / \mathrm{kg}$ ) [19].

The analysis of the ground environment assessment is also made in case of designation changes of the area, due to a change its development. Such tests were carried out, for instance, for the area of the railway yard designated for parking, where the petroleum hydrocarbon content was $110 \mathrm{mg} / \mathrm{kg}$ [20].

The assessment of soil quality resulting from the occurrence of adverse events is equally important. According to the research [21] in Louisiana, the content of petroleum pollutants in soils, in places of earlier oil spills, was for some individual locations $42.6 \mathrm{mg} / \mathrm{kg}$, or $85 \mathrm{mg} / \mathrm{kg}$ expressed as maximum average.

In contaminated soils, the content of petroleum hydrocarbons is often analysed depending on the depth. The amount of contaminants can diverse at individual levels. In one soil sample, depending on the layer, the values can be determined in the range from $36000 \mathrm{mg} / \mathrm{kg}$ up to $140000 \mathrm{mg} / \mathrm{kg}$ [22].

\section{Methodology}

The determinations of petroleum hydrocarbons in soils were made on the basis of PN-EN ISO 16703:2011 (Soil quality - Determination of hydrocarbon content in the range from $\mathrm{C} 10$ to $\mathrm{C} 40$ by gas chromatography) [1]. The range of quantification of the methodology described in the standard is from $100 \mathrm{mg} / \mathrm{kg}$ DM to $10000 \mathrm{mg} / \mathrm{kg}$ DM. Due to the lower expected values of the analysed compounds in the samples of collected soil, a calibration curve for low concentrations ranging from $200 \mathrm{mg} / \mathrm{L}$ to $8000 \mathrm{mg} / \mathrm{L}$ was made. The graph below (Fig. 1) shows the determined calibration curve. 


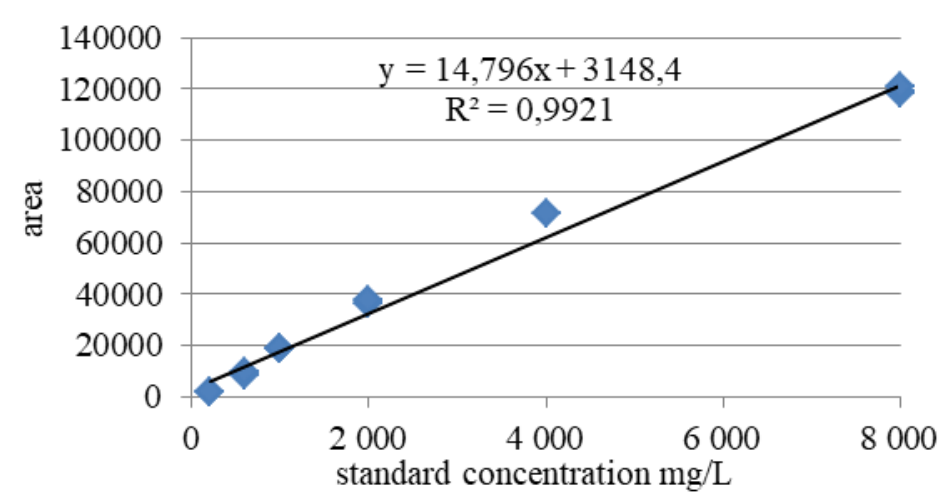

Fig. 1. The calibration curve for a mineral oil mixture standard using n-heptane as the hydrocarbon solvent.

The gas chromatograph with a flame ionization detector equipped with a Varian Capillary Column Select TM Mineral Oil LVI column $15 \mathrm{~m}$ long with a diameter of $0.32 \mathrm{~mm}$ was used for chromatographic analysis. The analysis time of a single sample was 36 minutes and proceeded according to the following temperature program: $80^{\circ} \mathrm{C}$ for $4 \mathrm{~min}$, $10^{\circ} \mathrm{C} / \mathrm{min}$ to $300^{\circ} \mathrm{C}$ and $300^{\circ} \mathrm{C}$ for 10 minutes. After receiving the results, from three replications, in the form of area under the curve, the values between which the difference was above $5 \%$ were rejected. The average was calculated from the remaining ones. The final result was calculated by means of the formula given in the standard [1] taking into account the data from calibration curve, the mass of the analysed sample and its dry matter content.

\section{Research}

In Polish law, the degree of soil pollution is based on The Regulation of the Minister of the Environment on the way of assessing the pollution of land surface based on land development [2]. The ground is divided there into four groups. The soil samples in the carried out research were qualified for group I (residential, service and recreational areas), groups II (agricultural areas) and groups IV (industrial and communication areas). According to this division and the depth from which the sample comes $(0-0.25 \mathrm{~m})$, the permissible amount of petroleum hydrocarbon is for group I $30 \mathrm{mg} / \mathrm{kg} \mathrm{DM}$, for group II $50 \mathrm{mg} / \mathrm{kg}$ DM and for group IV $3000 \mathrm{mg} / \mathrm{kg}$ DM.

In order to conduct a comprehensive analysis of the petroleum hydrocarbon amount in soils, depending on the land development, 16 soil sampling points were selected. All selected points were located in central Poland. The samples came from both sparsely populated and intensely urbanized areas and were divided into agricultural, service, recreational, residential and industrial use.

\subsection{The soil samples from areas used for agriculture $(1,2,3)$}

There were collected three soil samples deriving from agricultural areas. The first collection point was located in the vicinity of the provincial road, the second one was near wind turbines and the third one was next to the service road. The first two places are not urbanized (there are no buildings nearby). The last place can be considered as poorly urbanized because there are very few buildings in the immediate vicinity of the collection point. All analysed areas have always been used for agriculture purposes. 
The analysis showed that in the first point the soil was mostly contaminated with petroleum hydrocarbons (MOI content in soil was $471 \mathrm{mg} / \mathrm{kg} \mathrm{DM}$ ).

\subsection{The soil samples from service areas $(4,5,6,7)$}

The petrol stations from which the fourth, fifth and sixth samples have been taken are located by the expressway. There is a hotel in the vicinity of the first two stations. The sixth sample was taken from a place with a similar way of development to the fourth sample (at another kilometer of the same expressway). Before building the road, in each locations, there were farmlands, which are also now the basic landscape of these territories. Currently, the areas are poorly urbanized. Near the sixth place the car park for trucks is located.

The next sample point (7) connected with the service activity that could have an impact on the ground environment was a petrol station located in the medium urbanized area. The main buildings in the neighbourhood of the station are single-family houses.

The average value of petroleum hydrocarbons received from the analysed service area was $505 \mathrm{mg} / \mathrm{kg}$ DM.

\subsection{The soil samples from residential areas $(8,9,10)$}

In residential areas, apart from residential buildings, there is also infrastructure, the occurrence of which results from the intended use of the district. As a result, there are usually service points, car parks and public utility buildings in residential regions. The eight collected sample came from the unpaved surface, which was created after the demolition of the catering point. It is located in single-family housing. Opposite the square from which the sample was collected, there is a coal composition.

As the next locations for analysing the content of petroleum hydrocarbons in the soil, in the housing area, two extremely different points were selected. Both are located in the same housing estate, however one sample (9) came from the car park area, while the other was from the green area (sample 10). The estate is located in a highly urbanized area. In the neighbourhood of the collection points there are multi-family housing, road, public buildings and service points.

The analysis showed that minimum value of petroleum hydrocarbons from residential areas $(10 \mathrm{mg} / \mathrm{kg} \mathrm{DM})$ was determined for green surface.

\subsection{The soil samples from post-industrial and industrial areas $(11,12,13)$}

Two samples from post-industrial area and one from industrial were collected. The research material from the first post-industrial area (sample 11) came from the place where the construction materials had been produced. The factory operated until the early 90 's of $20^{\text {th }}$ century. For many years, the area was not used in any way. In recent years, the buildings have been demolished and the area has been prepared for housing investment. The content of petroleum hydrocarbons in the soil sample from this area was $687 \mathrm{mg} / \mathrm{kg}$ $\mathrm{DM}$, which is not so high value in relation to the activity which had been conducted in this area and the lack of any information regarding the reclamation of this ground.

Currently, former industrial areas are often adapted for service purposes. The area that was selected for the analysis (sample 12) was related to the textile industry. At the beginning there was a printing house for cotton fabrics, and later research centres and a textile laboratory. Presently, there are various service points on the analysed area (starting from gastronomy, through vehicle mechanics, and ending with tax services). The place is to 
some extent still related to a textile industry, as some of the rooms are occupied by textile companies. Not all buildings in this area have been fully renovated and being used.

The last soil sample (sample 13) came from an industrial area whose role was determined in the $60 \mathrm{~s}$ of $20^{\text {th }}$ century and has remained unchanged since then. Over the years, there have been many companies operating with various activities. A large part of the zone is occupied by storehouses. It should be noted that the sample originated from the public area, because there was no possibility to enter the area of many companies.

\subsection{The soil samples from recreational areas $(14,15$ and 16$)$}

Three samples were taken from recreational areas. The common feature of all objects is the presence of a water reservoir in their area. The first object (sample 14) was created in the 70 's of $20^{\text {th }}$ century. The water reservoir attracted investors and currently there are numerous recreation centers on the analysed area. The area around is largely used for agriculture. There are no factories and industrial facilities in the vicinity. The second recreational facility (sample 15) from which the sample was taken is an area that is located in an urbanized area. Around the object dominate single-family houses with the needed infrastructure. The number of buildings in this area is increasing each year. The last location (sample 16) of this type of development was the area, which is surrounded by cultivated fields and a car park of a nearby supermarket. There are catering points operating in the summer.

The average value of petroleum hydrocarbons received from the analysed service areas was $464 \mathrm{mg} / \mathrm{kg}$ DM.

\section{Results}

The achieved findings testify the poor quality of soils in the vast majority of selected areas. Most of the obtained values exceed the permissible limits [2]. The table below presents (Tab. 1) the area development of soil sample location, the limits of petroleum hydrocarbons amount according to standard [2], the analyses results with the achieved value of MOI and the percentage of exceeding the limits.

Table 1. The area development of soil sample location, the limits of petroleum hydrocarbons amount according to standard [2] and the analyses results with the achieved value of MOI and the percentage of exceeding the limits.

\begin{tabular}{|c|c|c|c|c|c|c|c|c|c|c|c|c|c|c|c|c|}
\hline $\begin{array}{c}\text { sample } \\
\text { number }\end{array}$ & 1 & 2 & 3 & 4 & 5 & 6 & 7 & 8 & 9 & 10 & 11 & 12 & 13 & 14 & 15 & 16 \\
\hline $\begin{array}{c}\text { area } \\
\text { develop- } \\
\text { pment }\end{array}$ & \multicolumn{3}{|c|}{ agriculture } & \multicolumn{4}{|c|}{ service } & \multicolumn{3}{|c|}{ residential } & \multicolumn{3}{|c|}{$\begin{array}{c}\text { post- } \\
\text { industrial*/ } \\
\text { industrial }\end{array}$} & \multicolumn{3}{|c|}{ recreational } \\
\hline $\begin{array}{l}\text { permissi- } \\
\text { ble value } \\
\text { mg/kg } \\
\text { DM [2] }\end{array}$ & \multicolumn{3}{|c|}{50} & \multicolumn{4}{|c|}{30} & \multicolumn{3}{|c|}{30} & \multicolumn{3}{|c|}{$30 * / 3000$} & \multicolumn{3}{|c|}{30} \\
\hline $\begin{array}{c}\mathrm{MOI} \\
\mathrm{mg} / \mathrm{kg} \\
\mathrm{DM}\end{array}$ & 字 & ' & ' & $\underset{\infty}{\stackrel{+}{\infty}}$ & $\stackrel{\infty}{0}$ & $\hat{n}$ & 。 & $\tilde{n}$ & 으 & $\stackrel{\infty}{=}$ & \&્ర & $\underset{\forall}{\stackrel{\sim}{f}}$ & గ్ర & $\underset{f}{\stackrel{N}{f}}$ & $\hat{n}$ & 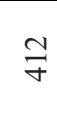 \\
\hline $\begin{array}{c}\text { limit } \\
\text { exceeding } \\
\text { by } \%\end{array}$ & $\underset{\infty}{\mathcal{N}}$ & ' & ' & 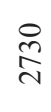 & $\widehat{\nwarrow}$ & $\stackrel{\circ}{\stackrel{+}{\Xi}}$ & $\hat{\text { d }}$ & $\underset{\infty}{\stackrel{\infty}{\infty}}$ & ' & $\hat{n}$ & $\stackrel{\curvearrowright}{\stackrel{2}{v}}$ & $\stackrel{\Re}{\stackrel{\Xi}{ \pm}}$ & & $\stackrel{?}{\text { 孚 }}$ & ஜ & $\stackrel{\cong}{\cong}$ \\
\hline
\end{tabular}

*Currently, due to the changed development the maximum permissible value for soil samples from post-industrial areas equals $30 \mathrm{mg} / \mathrm{kg}$ DM. 
The comparison (Tab. 1) clearly shows that the standards [2] are exceeded, in most cases, by over $1000 \%$. This situation results from the development of individual areas with facilities that had previously or have currently a negative impact on the soil environment.

The maximum value was achieved in the soil sample taken at the petrol station near the expressway (sample 4) and equaled $849 \mathrm{mg} / \mathrm{kg}$ DM.

The difference between the maximum and the minimum value in areas with a similar way of development is very large. For example, for the petrol station areas it was $740 \mathrm{mg} / \mathrm{kg}$ DM while for urban areas equaled $582 \mathrm{mg} / \mathrm{kg}$ DM. In the case of petrol stations, the difference is related to the number of users, while in the case of the urban areas it is dependent on the real (not necessarily correct) usage of the place.

Due to the fact that there are no other objects, near the first sample point collection except the road, it is very likely that the expressway has a negative effect on the adjacent farmland. This conclusion is based on the amount of petroleum hydrocarbons in the second and the third samples, in which the received amount of pollutants was below the used method of determination.

Considering the composition of petroleum hydrocarbons in soils from different locations, it is clearly visible (Fig. 2) that the fourth sample has a slightly different composition than the fifth sample (both from petrol station). However, despite various development, some of the studied locations, for example for recreation area and the area of petrol station, similar compounds appeared in analysed soil samples, which is visible in the presence of peaks in the chromatogram at the same time of analysis (Fig. 3).

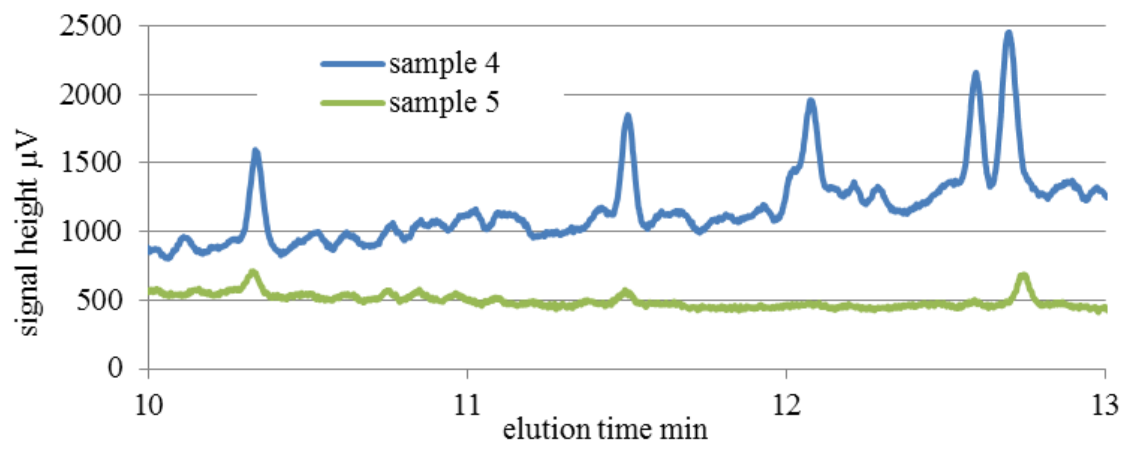

Fig. 2. The gas chromatograms of fourth and fifth soil sample in elution time between 10 and 13 minutes.

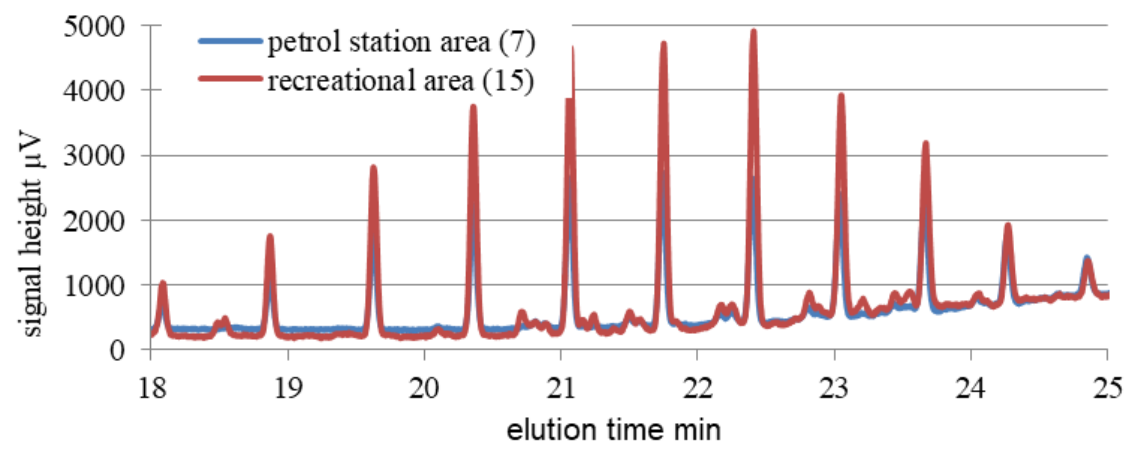

Fig. 3. The gas chromatograms for soil samples from various development area (recreational and petrol station area) in elution time between 18 and 25 minutes.

According to the legal requirements [2], some part of the analysed areas (residential area) meet the limits (green area) while the car park areas are too contaminated. All the 
areas have been assigned to group I according to the Regulation [2], where the maximum acceptable value of petroleum hydrocarbon is $30 \mathrm{mg} / \mathrm{kg}$ DM. It should be considered (for the $8^{\text {th }}$ sample, where the value of MOI was $592 \mathrm{mg} / \mathrm{kg} \mathrm{DM}$ ) whether further use of this place as a car park will not significantly contribute to the increase of soil contamination in the future. The bumpy surface of the car park may cause the accumulation of pollutants at certain points of the square.

Due to the development change of some analysed areas (post-industrial facility) it is crucial to recultivate the soil in the area. Then the requirements [2] concerning the content of petroleum hydrocarbons will be met.

It is unfavourable for environment that in all soils samples from recreational areas the value of petroleum hydrocarbons has significantly exceeded limits (at least $382 \mathrm{mg} / \mathrm{kg}$, by $1273 \%$ ). These areas are used for the rest, relaxation and the condition of environment should be on the highest level.

According to the literature data the amount of petroleum pollution in soils from places with theoretically similar development for example for petrol stations ranges from $79.9 \mathrm{mg} / \mathrm{kg}$ to $8075 \mathrm{mg} / \mathrm{kg}$ [17]. However, in the conducted research the values range from $109 \mathrm{mg} / \mathrm{kg} \mathrm{DM}$ to $849 \mathrm{mg} / \mathrm{kg} \mathrm{DM}$, which is near lower literature values.

The research indicates that the greatest risk related to the increase of pollution with petroleum hydrocarbons in the future may occur in soils near expressways (currently sample 1) that are exposed to car fluid leaks during breakdowns and damages to vehicles.

\section{Conclusions}

1. The current contamination level of soil environment depends on the place where the sample was collected and the depth of its collection.

2. Inadequate way of the area development (for example as unpaved parking space) and the lack of appropriate ground protection causes an uncontrolled increase in soil contamination.

3. The changes in the way of area development should make the property owners adjust the area to the effective law.

4. Monitoring of the soil environment should be constantly conducted to prevent its degradation.

\section{References}

1. PN-EN 16703:2011 (2011)

2. Regulation of the Minister of the Environment Jaw of Laws 2016, pos. 1395 (2016)

3. Report, European Environment Agency, https:/www.eea.europa.eu/data-andmaps/indicators/progress-in-management-of-contaminated-sites-3/assessment (2014)

4. A. G. Caporale, P. Adamo, F. Capozzi, G. Langella, F. Terribile, S. Vingiani, Sci. Total Environ. 643 (2018)

5. P. J. Harvey, M. Rouillon, C. Dong, V. Ettler, H. K. Handley, M. P. Taylor, E. Tyson, P. Tennant, V. Telfer, R. Trinh, Sci. Total Environ. 584-585 (2017)

6. F. B. V. Silva, C. W. A. Nascimento, P. R. M. Araújo, F. L. Silva, L. H. V Lima, Int. J. Environ. Sci. Technol. 14 (2017)

7. E. J. Bielińska, B. Futa, A. Ukalska-Jaruga, J. Weber, S. Chmielewski, S. Wesołowska, A. Mocek-Płóciniak, K. Patkowski, L. Mielnik, J. Soil Sediments, 18 (2018)

8. S. N. Sushkova, T. Minkina, I. Deryabkina (Turina), S. Mandzhieva, I. Zamulina, T. Bauer, G. Vasilyeva, E. Antonenko, V. Rajput, J. Soil Sediments, 18 (2018) 
9. D. Crnković, M. Ristić, A. Jovanović, D. Antonović, Environ. Monit. Assess. 125 (2007)

10. E. Mena, J. Villaseñor, M. A. Rodrigo, P. Cañizares, Chem. Eng. J. 299 (2016)

11. J. Rakowska, K. Radwan, Z Ślosorz, E. Pietraszek, M. Łudzik, P. Suchorab, https://www.cnbop.pl/wydawnictwa/ksiazki/usuwanie_substancji_ropopochodnych.pdf (2012)

12. J. Janzen dos Santos, L. T. Maranho, J. Environ. Manage. 210 (2018)

13. C. Riccardi, P. Di Filippo, D. Pomata, M. Di Basilio, S. Spicaglia, F. Buiarelli, Sci. Total Environ. 450-451 (2013)

14. E. Smith, P. Thavamani, K. Ramadass, R. Naidu, P. Srivastava, M. Megharaj, Int. Biodeterior. Biodegradation, 101 (2015)

15. I. Errington, C. K. King, S. Houlahan, S. C. George, A. Michie, G. C. Hose, Sci. Total Environ. 619-620 (2018)

16. D. Izdebska-Mucha, J. Trzciński, Geologija, 50 (2008)

17. B. H. Alharbi, M. J. Pasha, A. H. Alhudhodi, A. K. Alduwais, Soil Sediment Contam. 8 (2018)

18. J. Nowak, www.pfb.info.pl/files/kwartalnik/1_2008/nowak.pdf (2008)

19. A. Gao, J. Liang, T. Teng, M. Zhang, Appl. Soil Ecol. (to be published)

20. L. Bardel, https://bip.malopolska.pl/e,pobierz,get.html?id=1037479 (2014)

21. S. Chakraborty, D. C. Weindorf, B. Li, M. Nasim Ali, K. Majumdar, D. P. Ray, Environ. Pollut. 190 (2014)

22. G. Lassalle, A. Credoz, R. Hédacq, S. Fabre, D. Dubucq, A. Elger, Environ. Sci. Technol. 52 (2018) 